\title{
Communication, education and the social acceleration of time in Brazilian schools
}

\author{
ROGÉRIO PELIZZARI DE ANDRADE, University of São Paulo \\ DOUGLAS DE OLIVEIRA CALIXTO, University of São Paulo
}

\begin{abstract}
The phenomenon of the social acceleration of time goes beyond the limits of societal macrostructures and starts to resonate in different spheres of daily life. Based on empirical research applied to 3,700 students and more than 500 Brazilian teachers, this article aims to demonstrate how new temporal perspectives, generated by the dissemination of digital technologies, affect the daily lives of teachers and students. With the results of the study, we will seek to demonstrate how educators are subjected to stressful working hours and how they live intensely with acceleration mechanisms. Among students, the data reveal that, through their smartphones - used, even in the classroom - they rearrange the experience with time and the very sense of education.
\end{abstract}

\section{KEYWORDS}

Educommunication; social acceleration; smartphone; students; teachers

\section{Introduction}

The school and the teaching-learning processes are affected by the phenomenon of social acceleration. Among the elements that contribute to the effects of suppression and compression of time in classrooms are digital technologies. Especially through mobile devices, such as smartphones and tablets, the media cross the spaces and experiences of education, mediating the relationships between the different actors that comprise the school community.

In the Brazilian reality, marked by the low salaries of teachers and the absence of adequate infrastructure, the daily life of haste and speed gains specific contours. Teachers are obliged to undergo long working hours, often in more than one teaching unit and teaching different subjects for which they have often had no appropriate training. Among students, the social acceleration of time is related to the high use of digital social networks for social interaction. Ephemerality, impatience with school content and, above all, the 
intense use of smartphones are significant marks of the temporality experienced by young people in the school context.

These findings were generated from the research Inter-Relations Communication and Education in the Context of Basic Education, developed by the group Mediações Educomunicativas (MECOM), which has an institutional link with the School of Communications and Arts of the University of São Paulo, Brazil (ECA- USP). The study included a survey, which was carried out with a group of 3,700 students and more than 500 Brazilian teachers in the second half of 2018. The initial objective of the research, even before theconcept of the acceleration of time was included, was to identify how the media reconfigure sociability and interactions among Brazilian public education students.

Among the central hypotheses that guide the investigation is the perception that the shortening of the present, as well as the temporal experience marked by students' impatience, tense the school routine. The basic premise is that the social acceleration of time gives the contemporary world a structural mark, and the two fields of knowledge (Communication and Education) are re-signified, either by the logic of ephemerality of digital technologies, or by the compression of school time. These transformations represent an evident problem: there are, more and more, difficulties in concentrating and absorbing knowledge in the classroom, and the lack of tolerance and lack of interest in school contents are evident when subjugated in the face of technological fascination and the imperatives of haste and consumption. In this respect, the research aimed to test the hypotheses about temporal acceleration, obtaining data that could offer us analytical elements about this phenomenon in the teaching-learning processes.

Over the next few pages, we will present the research structure, based on the hypotheses raised, in addition to the choices and methodological criteria that guided the stage of formulating the questions and applying the research instrument. Then, we will deal with the theoretical framework that underlies not only the study, but also the outline proposed in this article, as well as discussing the data obtained from teachers and students. We will conclude with the analysis of information on the acceleration of time in the school context and the general comments regarding the social and economic macrostructure strained by the accelerated time.

\section{The construction of research}

Started in September 2018, the research Inter-Relations Communication and Education in the Context of Basic Education sought to gather data that contributed to the observation and analysis of changes in the school context due to the interaction of students and teachers with technologies, which, in our understanding, are strained by a new form of temporality.

We start from the perspective that accelerated life, which, according to authors like Crary (2014), tends to be enhanced by the media, crosses the school's daily routine, influencing, even, the activities in the classroom. In this sense, the set of questions formulated was 
basically organized in four blocks, which had the purpose of eliciting the following information: (i) the basic profile of the students and teachers who were part of the sample; (ii) the relationship they both have with the media; (iii) the extent to which the media are present, whether voluntarily or involuntarily, in formal education; and (iv) whether and how students and teachers are or feel impacted by the phenomenon of accelerating time.

The research design and application involved sixteen researchers ${ }^{1}$ directly. They were responsible for distributing the questionnaires used as a research tool in the five regions ${ }^{2}$ that make up the Brazilian territory, reaching 23 of the 26 states of the federation. In all, 509 teachers and 3,708 students in basic ${ }^{3}$ education answered the questions. Among students, $57.4 \%$ attended elementary school II and 39.8\% high school. Questionnaires were disseminated among teachers during visits to teaching units (on site) and through online strategies (at a distance), using physical and virtual ${ }^{4}$ forms. They were composed of 55 questions, 19 open and 36 closed. The same method was adopted with the students, among whom we circulated the instrument used to capture data both on digital and on paper, each adding 41 questions: 12 open and 29 closed. At this point, it is worth reiterating that the questions that make up the research were not restricted to topics related to the temporal issue, having also been investigated, for example, the changes in social relations in the school context due to new media habits. For this article, we cut out the specific questions on the form related to the topic studied here.

We chose to work with a non-probabilistic sample and, therefore, the study is devoid of statistical intent. Despite this, criteria were defined that would allow us to make the survey as comprehensive as possible, reaching the largest number of individuals, without it concentrating only on one or a few teaching units. Especially in relation to students, we established that the quantity of forms distributed could not exceed $10 \%$ of the total enrollment of the schools visited.

The procedure adopted for disseminating the questionnaire allowed for a variable range of possibilities. Visits were scheduled over the phone, we distributed digital versions

\footnotetext{
${ }^{1}$ Led by Professor Adilson Citelli, MECOM and the research involve the following associate researchers: Ph.D Ana Luisa Zaniboni Gomes, Ph.D Elisangela Rodrigues da Costa, Ph.D Eliana Nagamini, Ph.D Helena Corazza, Ph.D Maria do Carmo Souza de Almeida, Ph.D Sandra Pereira Falcão and Ph.D Rogério Pelizzari de Andrade; M.A. Edilane Carvalho Teles, M.A. Gláucia Silva Bierwagen, M.A. Suéller Costa, M.A. Douglas Calixto, M.A. Michel Carvalho da Silva and M.A. Wellington Nardes; Master student Roberta Takahashi Soledade; and Scientific Initiation student Rafaela Treib Taborda.
}

\footnotetext{
${ }^{2}$ The sample was distributed as follows in these regions: $1.2 \%$ in the North, $20 \%$ in the Northeast, $4.5 \%$ in the Midwest, $35.8 \%$ in the Southeast and $32.8 \%$ in the South.

${ }^{3}$ According to the Brazilian education system, basic education is integrated at three levels: early childhood (up to five years old), elementary (between six and 15 years old) and secondary (between 15 and 17 years old). Primary education is divided into two parts. The process of literacy and learning basic math operations, among others, marks the first, which runs from the 1st to the 5th year. In the so-called "early years", classes are divided into a few subjects and taught by multipurpose teachers, trained in pedagogy. The second comprises 6th to 9th grade. In it, students have contact with a greater number of educators, who are divided by subject. High school (1st to 3rd year) is intermediate to higher or technical. At this stage, basic subjects (languages, history, geography...) are incorporated, such as chemistry, physics and sociology.

${ }^{4}$ Made from the Google Forms platform
} 
through an email list on the pages of official education agencies, and there were those who went directly to the school and those who used Facebook profiles and fan pages and WhatsApp groups.

\section{Theoretical framework: social acceleration of time}

Before presenting the results obtained from the above method, we propose a theoretical review of the phenomenon of social acceleration of time and its implications in the school context. The questions formulated for the research start from the basic premise that, in addition to the instrumental and technical sense, the media play a determining role in the acquisition of knowledge, in the ways of being and perceiving the world. In other words, it is about the recognition that technologies are fundamental for the development of languages and for school sociability itself.

The research group MECOM develops works in this area, analyzing how the media, in the last decades, operates as a mediator of the teaching-learning processes. As Citelli (2004) states, "the classroom has become a place where - although not always visible or systematic - a complex intersection of diverse discursive orders and not necessarily adjusted or complementary." (p. 18)

Among the references addressed over the past few years, Rosa's (2019) perception of the paradox surrounding our relationship with technologies stands out. As much as the new devices are essential for optimization and saving time, which, in theory, would mean more freedom and flexibility, less occupations and responsibility, we simply do not have the time.

I conceptualize the acceleration process exposed here as a symptom and consequence of the fact that modern societies are able to stabilize only dynamically, to be systematically and structurally willing to grow, transform and accelerate more and more in order to preserve their structure and stability. (ROSA, 2019, X)

Our argument is that the structural changes experienced by contemporary society, at different levels, end up in the school's daily life. The classroom, affections and the very constitution of sociability between teachers and students are closely linked to the wider context of transition engendered by the fast pace of technologies and the operations of the economy. In this context, one of the central aspects of the work developed by MECOM researchers is to verify to what extent:

(...) rhythms traditionally accompany school speeches, tinted by slower movements, in line with the needs of reflection in their knowledge maturation pathways, coexist, dialogue or oppose the phenomenon here called the social acceleration of time. (CITELLI, 2017, p. 9) 
The process of accelerating the organizing structures of social life characterizes contemporaneity. The permanent pressure for efficiency, profit and competitiveness are hallmarks of the neoliberal dynamic, which results in new ways of relating to the world. We live under the aegis of an economic and normative system that extends the logic of capital-to-human relations. As a consequence, according to Dardot and Laval (2016), even individual behaviors are modulated to create an "accounting subjectivity due to systematic competition between individuals" (p. 30). Technologies meet the communicative demand to shorten deadlines, accelerate productivity and meet the global logic that "time is money". Morozov (2019) points out that the development of Silicon Valley and the Internet giants results in distrust of everything that is minimally consolidated, that is, the acceleration and frantic pace imposed by technologies create an environment in which our social existence can only be possible within transitory and ephemeral frameworks. The neoliberal subject, the neosubject (DARDOT \& LAVAL, 2016), wrapped in applications and digital tools, represents, ultimately, the triumph of the productive logic that transforms time into a financial asset.

The rhetoric of "technological advances" naturalizes the understanding that it is necessary to produce, consume and live at a pace 24/7, that is, twenty-four hours seven days a week (CRARY, 2014). Regarding this process of acceleration and fragmentation of life, Crary indicates that the demand for availability, functioning, intensity and permanent vigilance grows, which refers to an inability of lasting organizations, of rhythms and social stability. For Lipovetsky (2004), there is a new culture, which demands immediate satisfaction, the urgency of individual pleasures and ephemeral relationships. "In hypermodernity, there is no choice, there are no alternatives, but to evolve, to accelerate so as not to be overtaken by evolution" (p. 57).

The cult of novelty, speed and affect is the imperative. As Rosa (2019) proposes, the accelerated experiences are motivated by the technological development itself, which offers solutions to a market that is in a hurry and is eager for speed. Expressions such as fast food, speed learning, speed dating, power-nap, and multitasking exemplify the intensification of the pace of life and the shortening of the present, through the multiplication of digital and technological possibilities.

The fact that time becomes a scarce commodity represents in itself, in the face of the various technological accelerating phenomena, a paradox that requires explanation. For this reason, there is no doubt that the intensification of the rhythm of life through the multiplication of episodes of action and / or experiences per unit of time - which, in turn, is linked to the scarcity of temporal resources and the consequent "urgency for time"-- represents a third autonomous category of social acceleration in modern society (ROSA, 2019, p. 129)

It is in this sense that the temporal transformations reconfigure not only the perception of how the hands of the clock move, but also the structures that give order to social life. Thus, the understanding of the concept of communication is reconfigured from the idea that time has started to be accelerated socially. With this observation about the 
phenomenon, it is worth saying that the theoretical perspective that guides our research understands the nature of transformations in transit in the contemporary world from a pulsating philosophical line in the Latin American context: the theory of mediations. It is a theoretical-methodological approach, which recognizes communication, different media and technologies, within a broader concept of society, observing how sociability, culture and socio-political aspects interfere in the processes of media reception. The concept of mediations refers to the finding that, between the broadcast and reception by the media, there is an intense cultural and experience exchange between the subjects, determining how content is interpreted. In other words, the media does not configure passive subjects in face of messages and content, but rather triggers meanings and affections within a hybrid and complex game with the media. Or yet:

For us, communication has become a question of mediations rather than means, a question of culture and, therefore, not only of knowledge, but also of recognition. A recognition that was, at the beginning, a methodological shift operation to review the entire process of communication from its other side, that of reception, that of the resistances that have their place there, gives it appropriation based on its uses (MARTÍN-BARBERO, 1997, p. 28)

Communication and education studies in the Brazilian territory, the locus of our research, are highly influenced by the mediation theory. It was in this perspective that authors such as Paulo Freire, Mario Kaplún, Guillermo Orozco-Gómez and Jesús Martín-Barbero, from the 1970s onwards, developed theoretical models alternative to the idea that the media relate in a unidirectional way with the "audience ".The proposal, despite the particularity of each author, was to reconfigure the understanding of what communication is even before discussing insertion in the media at school. For these authors, the areas of communication and education must be worked in a relational way, without polarization, which implies the epistemological renewal, shifting the axis of analysis of communication from the sender-receiver to the relational-ecosystemic one.

In the current situation, in which liquidity, the ephemeral and the processes of deregulation in the economy prevail, mediation theory articulates the areas of communication and education to contribute to the observation of how the social acceleration of time enters the school territory.

The research Inter-Relations Communication and Education in the Context of Basic Education was guided by this theoretical framework, which shifts attention away from the effects and impacts of the media in the school context to the social reconfigurations generated by a socially accelerated time. The ideas presented here on the theory of mediations, in addition to the theme of social acceleration and its impacts on current societies, guided the process of defining methodological criteria, instruments and data collection that will be described and analyzed below. Considering the historical scenario marked by globalized capitalism, guided by the transitory, we seek to observe the impacts of temporal transformations in a specific space, which, especially after the multiplication of mobile communication devices, is crossed by the media: the school. 


\section{Search results}

\section{Results obtained from teachers}

Among the data obtained by the research, the first point that deserves to be highlighted is the strenuous workdays to which teachers are subjected, which result from low wages, precarious infrastructure and, of course, the accelerated dynamics of everyday life. Only $33.2 \%$ of the survey participants said that they carry out their activities part-time, that is, either in the morning, or in the afternoon, or at night. The others fulfill two periods $(49.7 \%)$ or triple the workday $(16.5 \%)$.

A little more than a third of the sample (35.2\%) works in more than one school and $15.9 \%$ stated that they are even obliged to travel between cities to take on the second or third shift.

Another variable that confirms the overloaded daily life among teachers is the weekly workload allocated to them. Almost two thirds of respondents $(61.9 \%)$ stated that they work more than 30 hours and just over a quarter (25.9\%) above 40 hours.

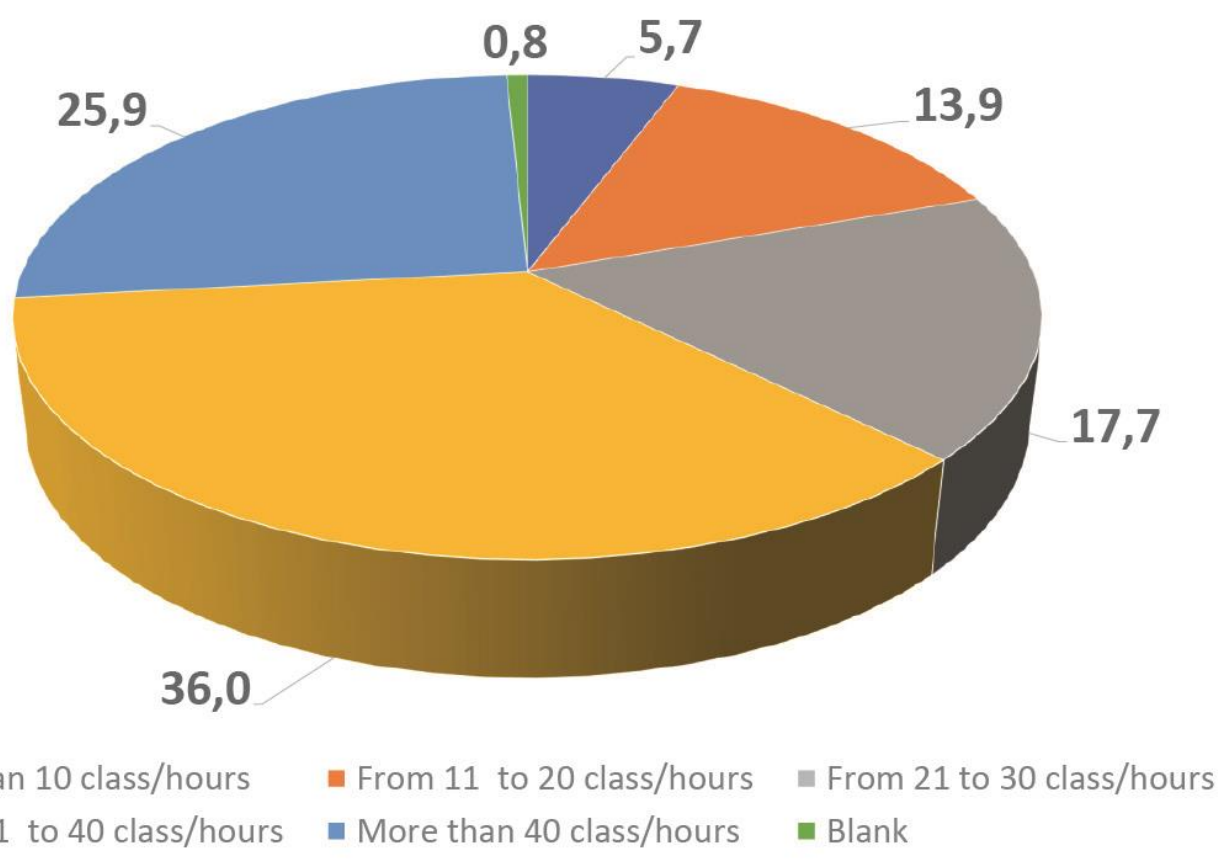

Source: MECOM, 2019

Graph 1 - What is your weekly workload? 
Thanks to communication devices, such as smartphones ${ }^{5}$, in addition to classes and other teaching duties, all exercised in the physical environment of the school, there are also responsibilities that go beyond these environments. The figures reveal that $34.2 \%$ of educators dedicate five hours or more of their week to the development of didactic activities with the aid of a computer and $44.2 \%$ stated that they use the internet to interact and share materials with students.

These data are likely to help explain the fact that more than half of respondents $(52.7 \%)$ consider the time available to prepare classes inadequate. In addition, the data obtained indicate the accumulation of tasks, which goes beyond formal obligations, and physical and mental exhaustion compromise the teacher's necessary relationship with other spheres of life, such as leisure, entertainment and idleness.

Asked how many hours of the week they invested in activities disconnected from professional obligations, such as going to the cinema, walking with the family and sports, among others, the majority (44.6\%) answered from 1 to 5 hours and only $12.2 \%$ indicated more than ten hours.

Graph 2 - The statement "There is a feeling that time is passing too fast" is:

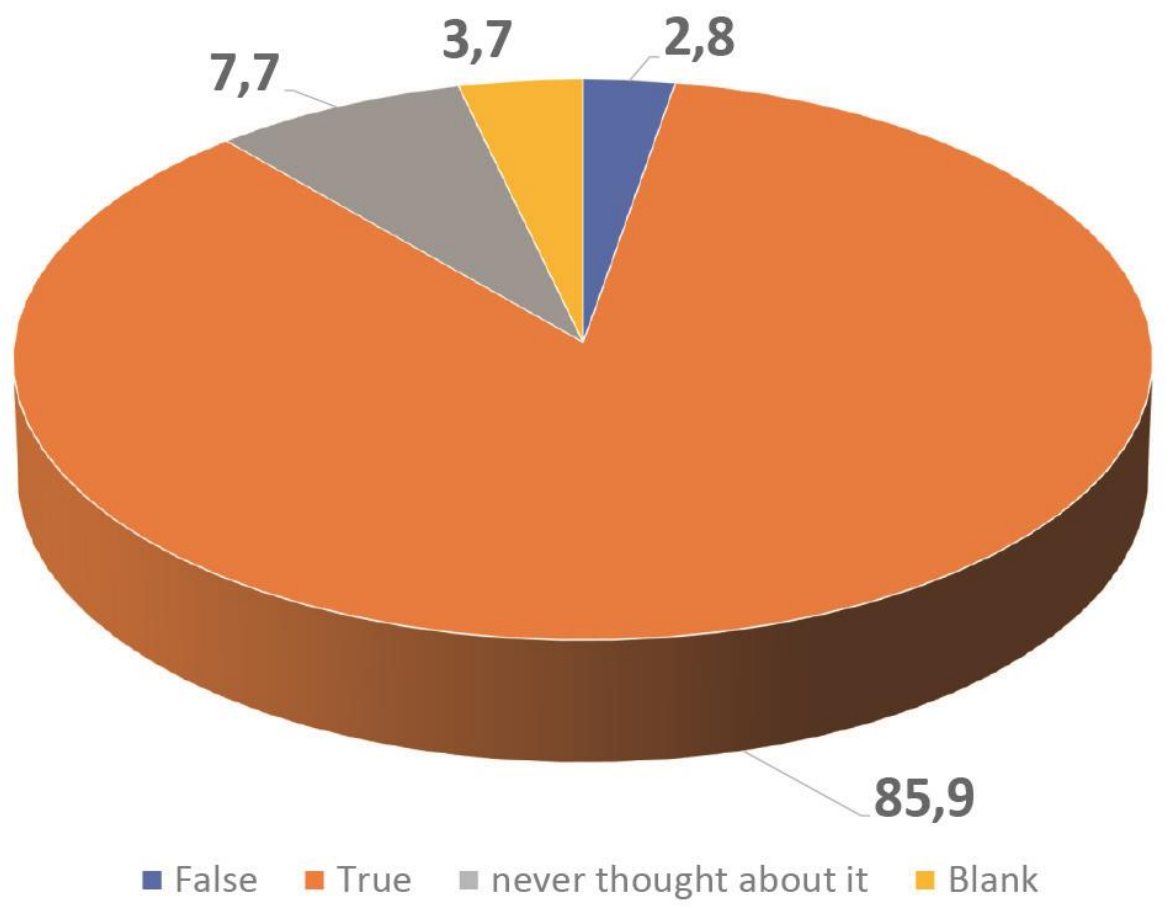

Source: MECOM, 2019

In view of the statement "There is a feeling that time is passing faster", $85.9 \%$ of the teachers who participated in the survey considered the sentence to be valid. In addition

$580 \%$ of educators use smartphones as the preferred means of accessing the Internet. Next are notebook / laptop (66.8\%) and desktop (41.3\%). 
and complementarily, we believe it is worth mentioning that in the understanding of $77.6 \%$ of teachers, social acceleration affects their pedagogical activities and $70.1 \%$ understand that it has some type of reflection in the behavior and practices of students in the classroom.

\section{Results obtained from students}

The general set of data collected by the survey indicates the growing importance of digital networks for the learning of reality, for media consumption and, above all, for the development of sociability among students. Although it has become commonplace to say that "new media" reconfigure the school context and that they insert "digital natives" in the dynamics of contemporary times, the result of our investigation points out that some applications such as WhatsApp, Facebook and YouTube are the main sources of information for these young people.

Among the hypotheses raised so far, this means that students are immersed in a networked logic, which, in essence, obeys acceleration flows. The timeline of social media on the Internet meets a communicative demand for fluidity, speed and personalized content, which does not require great reflections, maturation and patience for reading - practices that are fundamental in the teaching-learning process. Therefore, the main activities developed in these spaces value the exercise of the ephemeral, with little margin when looking in depth.

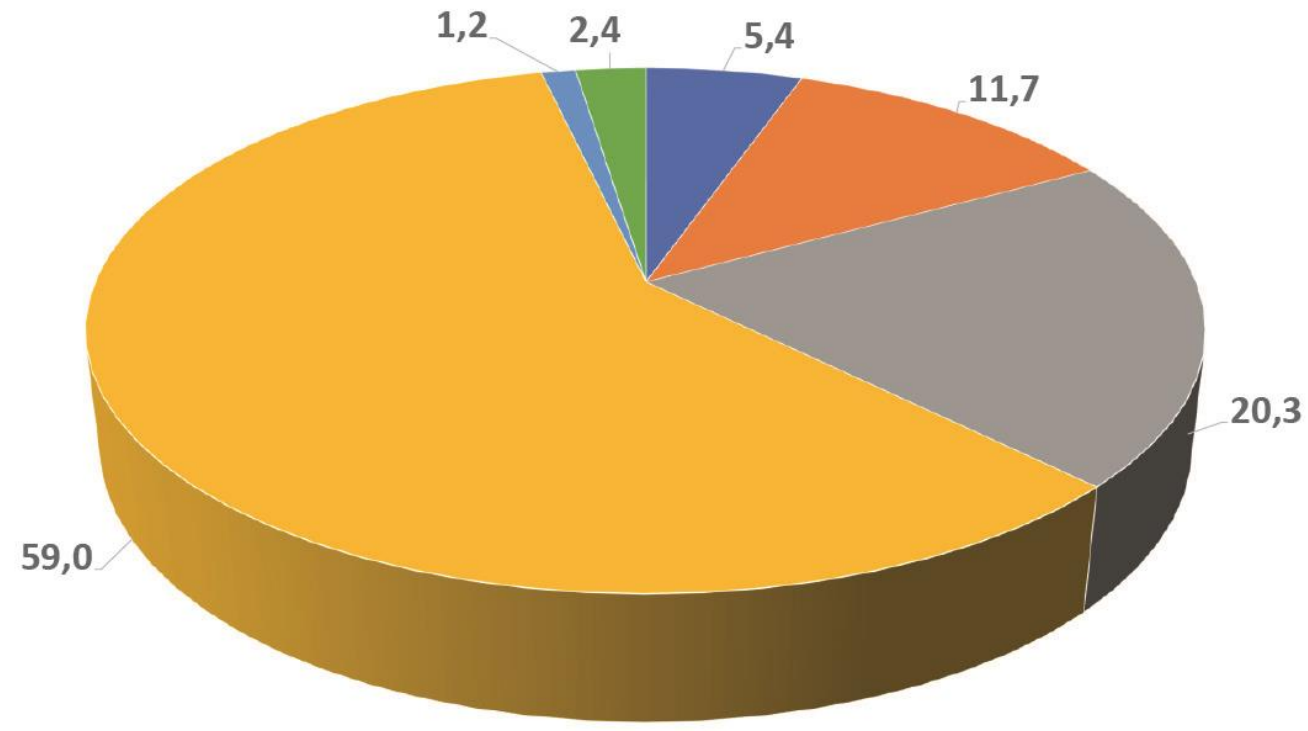

- Less than 1 - From 1 to 2 - From 3 to 4 more than 5 hours a day $\square$ I don't use $\square$ Blank 


\section{Graph 3 - How many hours per day do you use the Internet?}

A significant percentage of the participants (59\%) admitted to using the Internet for more than five hours a day, indicating that contact with the acceleration mechanisms is common even among the youngest students. Another fact that stands out in the survey is that students access the Internet mostly through smartphones ${ }^{6}(86 \%)$. The performance obtained is far superior to the second (notebook, with 32.4\%) and the third (SmartTV, with $24.6 \%$ ) places. The lack of mobility and the limitations imposed by desktop ${ }^{7}$ browsing make this feature uninteresting and obsolete for teen audiences, since the conventional microcomputer does not face the transitory possibilities of mobile devices, which can be everywhere - in the classroom, transportation, on the couch at home ... -, nor does it meet the desires for a permanent link with the "on-line".

Still in this perspective, when asked if they have already stopped doing any school assignment because they spent a lot of time on the Internet, $62.2 \%$ acknowledged that at least "sometimes" they exchanged their homework for the virtual environment. Likewise, $49.8 \%$ said that, at least, "from time to time" they access their cell phones during class and $39.1 \%$ that they share material with their friends, such as photos, memes and music, even while the teacher exposes content.

It should be noted that only $5.4 \%$ of students said they did not have a smartphone. The number draws attention considering the fact that Brazil is an underdeveloped country with enormous social contrasts. In addition, it is important to remember that the survey reached 23 of the 26 Brazilian states, more than $90 \%$ of the participants were from public schools and almost the same percentage was between 10 and 17 years old - factors that, in theory, should contribute to a higher sample proportion of people do not have a mobile communication service.

\footnotetext{
${ }^{6}$ Participants could choose as many alternatives as they wanted.

${ }^{7}$ Selected by $23.2 \%$ of participants.
} 


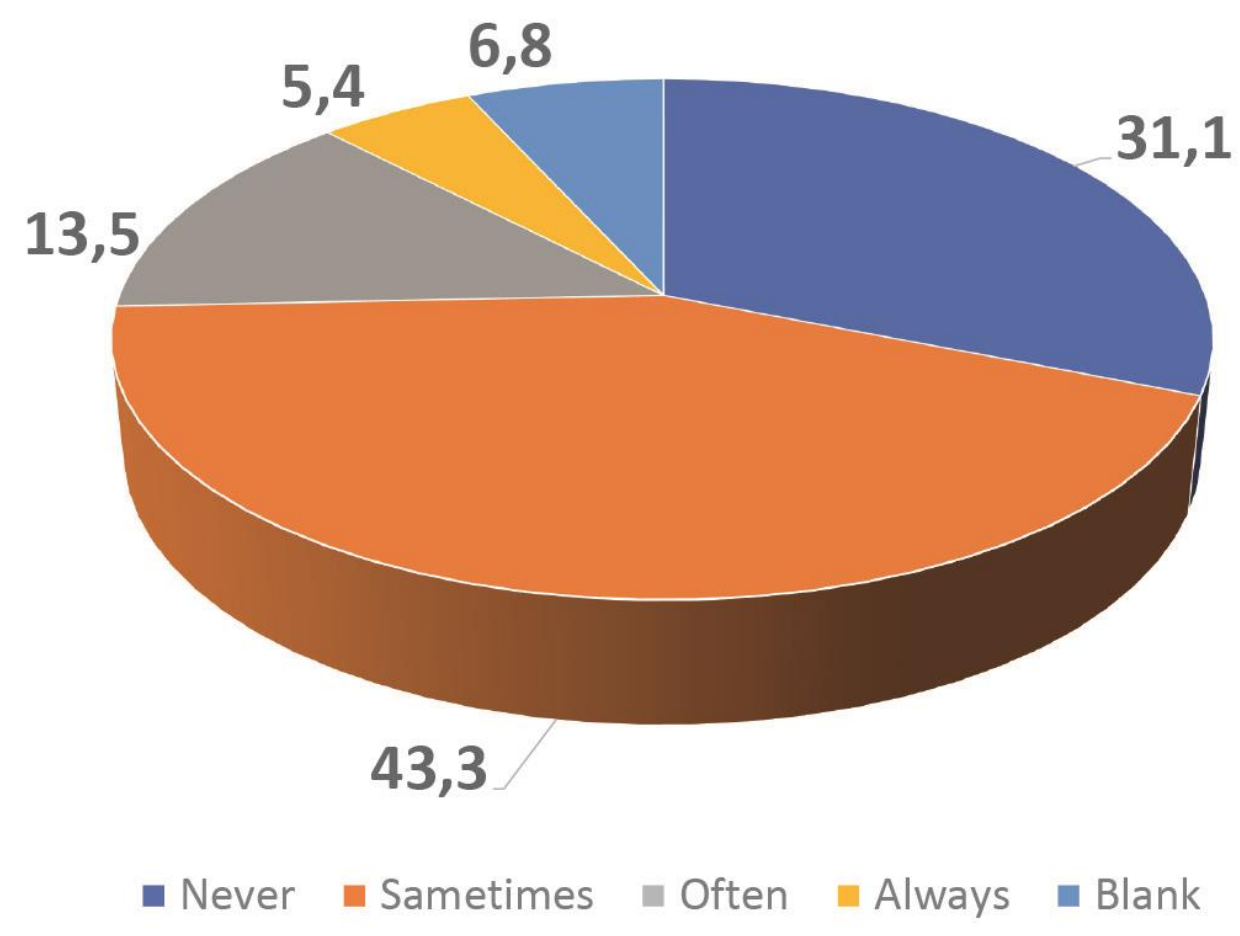

Source: MECOM, 2019

\section{Graph 4 - Have you stopped doing any school assignments because you have been connected to the Internet for a long time?}

Several testimonies collected from the 3708 students in open-ended questions point to signs of impatience and complaints about a time that passes slowly "outside" the Internet. We believe it is appropriate to emphasize that the young people interviewed have little identification with printed publications. Altogether, $78.3 \%$ declare not to read newspapers and $66.7 \%$ affirm not to read magazines in physical format, not even eventually. Multiscreen interaction, with several digital applications, generates more interest from students, which is confirmed by the finding that Facebook (65.2\%) and WhatsApp (68.5\%) appear as favorite options in a question about means they use most to get information.

\section{Analysis and discussion}

The set of data presented demonstrates how the phenomenon of the social acceleration of time goes beyond theoretical abstraction and manifests itself concretely in the educational context. The responses collected indicate that, when transported to school, the feeling that the days are shorter and that "lack of time" materializes in the impatience and disinterest of students in the classroom, with the excessive workload for teachers and with the fragmentation and simultaneity of experiences in both cases. 
Stress, haste, impatience, pressure for results, long journeys and disinterest, points out the result of the research, are the imperatives raised by the questionnaire respondents to express how the phenomenon of social acceleration manifests itself in the educational context. In fact, we observed based on the responses obtained, that digital technologies, especially smartphones and digital social networks, are among the main vectors of the acceleration mechanisms.

As Crary (2014) reminds us, the disconnect function lost its meaning in the era of digital technologies, so that the time of work, study, leisure, rest etc. ended up overlapping, mixing and becoming one. In the book "After the future" (2019), Franco Berardi expands this discussion and proposes reflection from the centenary of the publication of the Futurist Manifesto, by Filippo Tommaso Marinetti, in 1909, in the French newspaper Le Figaro. Berardi discusses the contrast between Marinetti's optimistic view of machines and technologies at the beginning of the 20th century and the despair scenario of our day. According to the optimistic perspective outlined at the beginning of the last century, the good news materialized in innovations, in the expansion of electricity, in the mechanization of the world, in discoveries and inventions: science indicated a future of conquests and prosperity. Progress would give man a better, more just, more dignified life, with more quality.

Capitalism, which is the "system of constant economic expansion", of which it is impossible to speak without thinking of "accelerating working time" $(2019$, p. 18) and expanding the productive capacity associated with the increase in speed, contributed to the deterioration of the best expectations announced in the text that circulated on that already somewhat distant February 20. Over the little more than one hundred years that have passed since then, the future of positivity and perseverance has become the gift of inconstancy and pessimism. Conditions worsened with the development of digital technologies, since we quickly realized that the expansion of cyberspace couldn't be accompanied by the prolongation of the time of concrete life, of the here and now.

\footnotetext{
When each millimeter of terrestrial space had been colonized, the colonization of the temporal dimension began, that is, of the lived, of the mind, of perception. Then the century without a future began. The question that arises here is the one of the relation between unlimited expansion of cyberspace and the limits of cyber time. Cyber time is mental time, the attention that society is able to maintain. (BERARDI, 2019, p. 19)
}

If physics clarifies that it is not possible to subvert or lengthen the seconds, minutes and hours of a day, what remains for us is to review the way we occupy each unit of time and intensify the parallel and simultaneous activities, with a view to maximizing of experience. As Dardot and Laval affirm, "The new subject is required to produce" always more "and enjoy" always more "and, in this way, connect directly with a 'more-to-enjoy' that has become systemic." (2016, p. 355)

Starting from the premise of Rosa (2019) that modernization is an accelerating experience, we observe that the occupation of time mostly done on social networks 
reveals that students are undergoing a broad process of acceleration. In this sense, not only Rosa's ideas, but also those of Berardi, Crary, Dardot and Laval, reflect the results obtained from the data collected in the research. The most solid, structured and lasting relationships lose space in the face of fragmentation, short videos and immediate pleasures. During the application of the questionnaires, we collected a series of testimonials from students who declare their preference for reduced formats for interacting with knowledge and acquiring knowledge. The choice, in general, is directed to short audiovisual content, memes and other languages that meet the logic of ephemerality and instantaneity.

It is no accident that fragmented formats, such as speed learning, have also gained prominence in recent times. Students, in general, show little patience when dealing with denser, more reflective readings that do not meet expectations due to haste and customization. In practice, the change in access and information consumption habits reconfigures the logic not only of classroom practices, but also in the way we deal with textual communication in its physical version. This is because a book, newspaper or magazine, for example, tends to promote slower experiences, as they usually offer longer content, in some cases permeated by advertisements and other products not necessarily interconnected.

Now the preference is for fast digital information, found in multiple formats and, in general, added to hypertexts. This context enhances the experience of absence of fixed hours and transforms the screens of mobile devices into a kind of primary source of knowledge. Short videos, memes, GIFs and other narrative expressions from the internet, composed of direct and instant messages, are opposed to textual productions that demand more close contacts and with which students have to interact in formal education. This fact reveals that the shortening of the present occurs not only in reading, but also in the very constitution of language.

However, to deepen the analysis, it is essential to consider that the phenomenon of social acceleration of time does not act unilaterally in the interactions of teachers and students, although the results indicate that the shrink present perfect gives a structural mark to the school experience. In the Brazilian context, there is a serious scenario of inequalities, which further strain the already troubled daily life of ephemerality and loss of meaning in the classrooms.

According to the "Brazilian Yearbook of Basic Education 2019", published by the civil society organization Todos pela Educação, which gathers information from different sources such as the Ministry of Education and the National Institute of Educational Studies and Research Anísio Teixeixa (INEP), in 2018, the average salary of the little more than 2.2 million teachers who are part of the public school system was $\mathrm{R} \$ 3,823$ BRLs or US\$ $916.61^{8}$. Distributed by the 26 states of the federation, this contingent of

\footnotetext{
${ }^{8}$ Quotation by the Central Bank of Brazil on October 16, 2019, available at: <https://www.bcb.gov.br / conversion>. Accessed October 17, 2019.
} 
educators contributes to the training of 48.4 million students (INEP, 2019) ${ }^{9}$, who, as indicated by national and international assessments, do not perform well even in the basic subjects. In the latest report published by the International Student Assessment Program (PISA), for example, young Brazilians were among the last positions in a ranking with more than 70 countries. According to the study, our students were ranked 59th in reading and 65th in mathematics (OECD, 2015) ${ }^{10}$.

The context of social inequality and public services that do not effectively affect the majority of the Latin American population is reflected in social interactions, in individual and collective experiences linked to knowledge. It is these premises that, added to the phenomenon of social acceleration and technological growth, end up severely impacting the dynamics of the classroom. In practice, this means that the acquisition of knowledge and the construction of knowledge itself are not autonomous processes, which work despite inequalities and technological implications.

\section{Conclusions}

The Inter-Relations Communication and Education project in the Basic Education Context is the breakdown of activities started in the second half of 2015. Supported by the first readings on the topic, researchers linked to MECOM proposed the initial approximations between the issue of social acceleration and concerns occupying the field of Educommunication ${ }^{11}$. In addition to participating in congresses inside and outside Brazil, the discussions yielded ten individual studies, which involved empirical surveys and were published in the work Communication and education: the challenges of the social acceleration of time (CITELLI, 2017).The construction, planning and execution of the research instrument occupied 2018. In 2019, the work focused on tabulation and analysis of data that motivated the production of this and other papers. Five years after the first dialogues and reflections, which started from more comprehensive concepts

\footnotetext{
${ }^{9}$ Information on numbers of registered teachers and students can be obtained from the national survey published by INEP annually. National Institute of Educational Studies and Research Anísio Teixeira. Statistical Synopsis of Basic Education 2018. [online]. Brasília: Inep, 2019. Available at: $\langle$ http://inep.gov.br/web/guest/ sinopses-estatisticas-da-educacao-basica〉. Accessed October 17, 2019.

${ }^{10}$ The full report is available at: 〈http://www.oecd.org/pisa/pisa-2015-results-in-focus.pdf >. Accessed on October 17, 2019.

${ }^{11}$ The neologism Educommunication, according to Soares (2014), "designates a field of social intervention at the interface between communication and education" (p. 16), which developed in Latin America from the second half of the twentieth century and approaches the ideas formulated by Cultural Studies. The theoretical framework that guides this "field of social intervention" includes authors such as Paulo Freire, Mario Kaplún and Jésus Martín-Barbero. The School of Communications and Arts of the University of São Paulo (ECA / USP) offers undergraduate and graduate education (specialization, master's and doctorate) courses in this line of research. The Educational Communications Group (MECOM) is formally linked to it.
} 
towards specific problems, we confirm the hypotheses formulated even in the period of approximation of the theoretical framework. They referred to the impacts of social acceleration on formal education, motivated by variables such as the exhausting routine of teachers, in addition to the daily life of the school and its actors, which is marked by the presence of communication devices. Furthermore, the attentive look at the data collected allows us to observe the gap between times: "we can deduce the existence of a picture in which there is an evident tension between the movements of institutionally school time and that crossed by the acceleration devices" (CITELLI, 2019, p. 11).

In July 2020, as we write the last lines of this article, we are compelled to state that MECOM discussions will necessarily turn to the transformations resulting from the COVID-19 pandemic. The adaptations of human relationships imposed by the need for social distance, as well as the emergence of new forms and experiences of communication and, in the case of teaching, the challenge of introducing comprehensive distance learning methods and strategies in such a short period of time - especially in a country of continental dimensions and marked by so many contrasts - they offer new elements to studies whose interests focus on the convergence between the themes of social acceleration, communication and education.

\section{References}

BERARDI, F. (2019) Depois do futuro. São Paulo: Ubu.

CITELLI, A. O. (2004) Comunicação e educação: A linguagem em movimento. $3^{a}$ Ed. São Paulo: SENAC.

CITELLI, A. O. (Org.). (2017) Comunicação e educação: os desafios da aceleração social do tempo. São Paulo: Paulinas.

CITELLI, A. O. (2019). Comunicação e educação: dinâmica do tempo. $42^{\circ}$ Congresso Brasileiro de Ciência da Comunicação - INTERCOM, 2019, Belém. Disponível em: <https://portalintercom.org.br/anais/nacional2019/resumos/R141176-1.pdf>. Acesso em: 23 jul. 2020.

CRARY, J. (2014) 24/7: capitalismo tardio e os fins do sono. São Paulo: Cosac Naify.

DARDOT, P. \& LAVAL, C. (2016) A nova razão do mundo - ensaio sobre a sociedade neoliberal. São Paulo: Boitempo.

FREIRE, P. (2016) Pedagogia do oprimido. Rio de Janeiro: Paz e Terra.

INSTITUTO NACIONAL DE ESTUDOS E PESQUISA EDUCACIONAL ANÍSIO TEIXEIRA. (2019) Sinopse estatística da educação básica 2018. [online]. Brasília: Inep. Disponível em: < http://inep.gov.br/web/guest/ sinopsesestatisticas-da-educacao-basica>. Accessed October 17, 2019.

LIPOVETSKY, G. Os tempos hipermodernos. Tradução: Mário Vilela. São Paulo: Editora Barcarolla, 2004. 
MARTíN-BARBERO, J. (2014) A comunicação na educação. São Paulo: Editora Contexto.

MARTíN-BARBERO, J. (1997). Dos meios às mediações: comunicação cultura e hegemonia. Rio de Janeiro: UFRJ.

MOROZOV, Evgeny. Big Tech: a ascensão dos dados e a morte da política. São Paulo: Ubu Editora, 2018.

ORGANIZATION FOR ECONOMIC COOPERATION AND DELEPOMENT (OECD). (2018) PISA 2015: results in focus. Paris: Pisa, OECD. Disponível em: $<$ http://www.oecd.org/pisa/pisa-2015-results-in-focus.pdf.>. Accessed October 17, 2019.

ROSA, H. (2019) Aceleração: a transformação das estruturas temporais na modernidade. São Paulo: Unesp.

SOARES, I. de O. Introdução à edição brasileira - A educomunicação na América Latina: apontamentos para uma história em construção. In: APARICI, Roberto (Org.). (2014) Educomunicação: para além do 2.0. São Paulo: Paulinas. pp. 7-26.

TODOS PELA EDUCAÇÃO. (2019) Anuário brasileiro de Educação básica 2019. São Paulo: Moderna.

\section{Biographies}

Rogério Pelizzari de Andrade holds a PhD in Communication Sciences from the School of Communications and Arts of the University of São Paulo (ECA / USP/ Brazil). He is research at MECOM (Resarch Group Educational Mediations) and develops works focused on youth practices mediated by communicative devices, with special interest in the musical references of students of basic education.

Email: rpelizzari@alumni.usp.br

Douglas Calixto is a $\mathrm{PhD}$ student in Communication Sciences from the School of Communications and Arts of the University of São Paulo (ECA / USP/ Brazil). Develops research in Educommunication and technologies. He is currently Communication Supervisor at the Brazilian Institute of Criminal Sciences (IBCCRIM) and a researcher at MECOM (Research Group Educational Mediations).

Email: dcalixto@usp.br 